\title{
Impact of Agriculture and Land Use on Ground Water Quality: A Case Study of Ladakh Cold Arid Region
}

\author{
Jigmet Yangchan ${ }^{1}$, Sonam Dawa ${ }^{2 *}$, M. S. Raguwanshi, \\ Phuntsog Tundup ${ }^{4}$ and Vikas Gupta ${ }^{4}$ \\ ${ }^{1}$ HMAARI, SKUAST-K, Leh-Ladakh-194101 (J\&K), India \\ ${ }^{2}$ National Research Institute for Sowa-Rigpa (NRIS)-Leh, CCRAS, Ministry of AYUSH, India \\ ${ }^{3}$ ICAR-National Bureau of Soil Survey and Land Use Planning, Nagpur-440033 (MS), India \\ ${ }^{4}$ Krishi Vigyan Kendra (KVK)-Stakna, SKUAST-K, Leh-Ladakh, India \\ *Corresponding author
}

\section{A B S T R A C T}

\section{Keywords}

Fertilization, undecomposed manure, ground water, water reservoir.

\section{Article Info}

Accepted:

15 August 2019 Available Online:

10 September 2019
Water reservoirs are always characterized for drinking water quality. However, in catchments where arable fields dominate, the impact of agriculture on water pollution is still problematic. In Ladakh, recently the fertilization level has decreased drastically due to detrimental impact on soil conditions, mostly for economic reasons as well as lastly getting more awareness on benefits of organic farming towards maintaining indigenous traditional knowledge/ methodologies. However, almost few villages still apply fertilizers as starter dose to boost the crop emergence as well as adding un-decomposed manure cum night soil in their field due to declining trend in livestock size per household. In order to evaluate the impact of agriculture on water quality in a water reservoir with a high proportion of arable fields adjoining to reservoir were monitored. Present study was carried out in Gangles Gompa village situated $5 \mathrm{~km}$ upper side of Leh market with stone meant to provide drinking water for $40 \%$ population of Leh city. The aim of the study were to assess (1) the impact of agriculture land on groundwater, and running water quality and (2) impact of drains on aquatic animals and human health.

\section{Introduction}

Water reservoirs for drinking purpose are expected to be characterized by good water quality. However, in catchments area where arable fields dominate, the impact of agriculture on water pollution becomes important. Eutrophication is a key factor causing degradation of water quality, which 
restricts its use. Recently, agriculture is recognized as a major source of water pollution, (Billen et al., 2013; Fowler et al., 2013). Degradation of soil and water from agriculture occur due to residues of used chemicals (pesticides), emission of ammonium, methane or sulfide from livestock production, and livestock manures. One of the most problematic is nitrogen and phosphorus leaching from arable fields to groundwater and surface water as a result of higher amounts of these nutrients applied in natural and mineral fertilizers compared to plant requirements or supplied in adverse conditions (Billen et al., 2013; Kyllmar et al.,2014 b). The major excessive $\mathrm{N}$ inputs from agriculture have been identified as a major contributor to stream $\mathrm{N}$ loadings (Boyer et al., 2002, Hatano et al., 2005; Garnier et al., 2010). Nutrient leaching depends on several factors: primarily fertilization level, type, and timing of fertilizer application; the method of their application to the soil; properties of soils (i.e., $\mathrm{pH}$, structure and organic matter content), types of crops and their fertilizer requirements; method of cultivation and agronomic practices; and the level of animal production (Bechmann 2014, Kyllmar et al.,2014a and 2014(b)). Weather conditions and catchment land use also have a crucial impact on the intensity and quantity of nitrogen leaching (Jiang et al.,2014; Yoon 2005; Woli et al.,2008).

A key factor in determining plant nutrient uptake is also the availability of micro- and macro-elements in the soil, particularly mass ratios between elements (Cakmak 2005; Fageria 2001; Güsewell et al., 2003; Szczepaniak et al., 2013). An insufficient amount of potassium reduces nitrogen uptake by plants and thereby may increase nitrogen leaching from soil (Lawniczak et al., (2009) and Lawniczak (2011). Also, deficient availability of phosphorus causes decreased plant biomass, even when nitrogen is in an optimal concentration compared to plant requirements (Güsewell 2004. However, relationships between these elements are not well understood in terms of nutrient leaching in agricultural areas.

Nitrogen, in particular the very soluble nitrate, is easily dissolved into the percolating water. Phosphorus is less mobile and reaches surface water due to erosion with the bound soil particles. These different pathways cause a problem with water protection, because elimination of one water pollution source may aggravate another. For example, reduction of fertilization level or one of the elements may not reduce leaching of nutrients as a result of the unfavorable ratio of nutrients in soil. Deficiency of phosphorus or potassium limits the uptake of nitrogen by plants, even when the nitrogen level is sufficient (Lawniczak et al., 2009). This suggests that at a low level of fertilization due to shortage of potassium and phosphorus, there may occur loss of nitrogen, which results in water and soil pollution. This issue may concern two thirds of the world's agricultural land where potassium deficiency occurs (Romheld and Kirkby 2010).

The necessity of measures to reduce the negative impact of agriculture on water quality results from the provisions of European Commission Council Directive 91/676/EEC (i.e., the Nitrate Directive) concerning the protection of waters against pollution caused by nitrates from agricultural sources. In Poland, these activities are obligated in the designated Nitrate Vulnerable Zones (NVZs), which were introduced as special actions based on local law. However, nitrogen pollutants affect more areas (Iital et al., 2014; Rozemeijer et al., 2014; Wendland et al., 2009), even where the nitrate level is exceeded occasionally. Particularly, they should be focused on protected areas that are characterized by a large proportion of agricultural land. 
The Wielkopolska region is one of the most developed agricultural areas in Poland. A high proportion of agricultural land cover types in the region carry the risk of water pollution. The fertilization level in this part of Poland was always higher than in other parts of Poland (GUS 1952-2013). However, recently, these differences significantly decreased and application of fertilizers is at the level recommended in terms of water and soil protection against pollution from agricultural sources (Codex of Good Agricultural Practice 2004).

In order to recognize the impact of agriculture, particularly supply of fertilizers, on water quality in the protected area, complex monitoring has been applied. The study was carried out in Wielkopolska National Park and its buffer zone, which are also protected as Natura 2000 sites. In this area, open water bodies are characterized by poor water quality (Lawniczak unpublished results). Knowledge of the impact of agriculture on groundwater quality, particularly the most problematic nonpoint sources, is crucial for a proper protection strategy for this area.

The aim of the study were (1) to assess the impact of agriculture, particularly fertilization and un-decomposed manure, on quality of groundwater and running water; (2) Induces of drainage of water on aquatic animals and human health (3) to provide recommendations and suggestions for conserving valuable water reservoir.

\section{Study area}

The study was carried out in the GanglesGompa dug-well water reservoirs, located in the Gompa village, about $5 \mathrm{~km}$ from Leh main bazaar at an elevation in between $34^{\circ} 12^{\prime}$ $77^{\circ} 35^{\prime}$ to $34^{\circ} 11^{\prime} 77^{\circ} 35^{\prime}$. The dug-well was established around in 1980 by PHE department drinking water supply for Leh city. The concept of this dug well is to collect the discharge getting from spring and deliver to public for drinking purpose and to reduce the human impact as well as animal on the pond and also improve the efficiency of pond protection of fencing were also done.

Currently, the pond fencing was damages from one side, the whole concept behind this dug well get reversed in which dogs and cow dropping, instead of spring water, drainage of agriculture as well as 50\% chances of septic water also enters in this dug well by the observation of farmers in this area as well our observation in field. This water level of dug well remains low in winter season. Once the irrigation started in summer the pond water level started rising.

As the chances of leaching and seepage from the agriculture as well as from septic tanks of habitats in this dug well is around $90 \%$ due to high elevation of field and habitats then dug well. Still $40 \%$ of water is delivered by PHE to Leh city in which following areas were covered, Part of Gonpa, Sankar, Lamdon, Chupi, Zangsti etc are still cover through this dug well for drinking purpose.

\section{Materials and Methods}

The study was carried out during year 2018-19 as per questions raised by Gompa village farmers that lots of small worms and sometime received dead fish from their drinking water have been observed from tap water supply. On report, main water reservoir was observed accordingly and water testing carried out with the help of TDS, $\mathrm{pH}$ meter, using VSI water testing kit in which physical property of water quality were tested per the ecological status of dug well.

Judge the following data provided by Department of Agriculture on utilization of chemical fertilizer use in Leh District (unit quintals) may be the one cause of water pollution. 


\begin{tabular}{|c|c|c|c|c|}
\hline Year & Urea & DAP & MOP & Total \\
\hline $\mathbf{1 9 9 0}$ & 3537 & 1795 & 37 & 5369 \\
\hline $\mathbf{1 9 9 1}$ & 4172 & 2157 & 52 & 6384 \\
\hline $\mathbf{1 9 9 2}$ & 4369 & 2237 & 90 & 6696 \\
\hline $\mathbf{1 9 9 3}$ & 3544 & 592 & 33 & 4171 \\
\hline $\mathbf{1 9 9 4}$ & 3741 & 1034 & 13 & 4788 \\
\hline $\mathbf{1 9 9 5}$ & 5814 & 1809 & 19 & 7642 \\
\hline $\mathbf{1 9 9 6}$ & 3567 & 1345 & 1 & 5913 \\
\hline $\mathbf{1 9 9 7}$ & 4310 & 1563 & 106 & 5979 \\
\hline $\mathbf{1 9 9 8}$ & 7055 & 2830 & 55 & 9940 \\
\hline $\mathbf{1 9 9 9}$ & 5542 & 2352 & 8 & 7902 \\
\hline $\mathbf{2 0 0 0}$ & 3693 & 1894 & Nil & 5587 \\
\hline $\mathbf{2 0 0 1}$ & 4003 & 2035 & 71 & 6109 \\
\hline $\mathbf{2 0 0 2}$ & 3756 & 2245 & 32 & 6033 \\
\hline $\mathbf{2 0 0 3}$ & 2296 & 1842 & Nil & 4138 \\
\hline $\mathbf{2 0 0 4}$ & 3570 & 2430 & 68 & 6068 \\
\hline $\mathbf{2 0 0 5}$ & 3537 & 2566 & 10 & 6113 \\
\hline $\mathbf{2 0 0 6}$ & 3710 & 2626 & 8 & 6344 \\
\hline $\mathbf{2 0 0 7}$ & 3748 & 2965 & 1 & 6714 \\
\hline $\mathbf{2 0 0 8}$ & 3660 & 2719 & 75 & 6454 \\
\hline $\mathbf{2 0 0 9}$ & 4058 & 3187 & 119 & 7364 \\
\hline $\mathbf{2 0 1 0}$ & 3735 & 3341 & 165 & 7241 \\
\hline $\mathbf{2 0 1 1}$ & 3547 & 3177 & 10 & 6734 \\
\hline $\mathbf{2 0 1 2}$ & 3689 & 3489 & 142 & 7320 \\
\hline $\mathbf{2 0 1 3}$ & 3606 & 3378 & 107 & 7091 \\
\hline
\end{tabular}

In initial stage this dug well is only design for harvest spring water still today it supply drinking water in $40 \%$ of Leh area includes (Gompa, Chubi, Khakshal, Lamdon, Police Thana). But during summer and during irrigation period the water level reach up to half of dug well as compared to normal water level in winter. During observation it was noticed that most of the area under arable fields in the catchment. Impact of agriculture land and habitats which is located at higher elevation compared to pond is positive and $60 \%$ Algae blossom in dug well. Shirley Sharpe mention in aquarium that nitrate levels as low as $10 \mathrm{ppm}$ will promote algae growth. Algae blooms in newly setup well due to elevated nitrate levels. Similarly, Dolma et al., 2015 reported in Baseline Study of Drinking Water Quality-A Case of Leh Town, Ladakh (J\&K), India it was observed the nitrate content of water samples in the study area was varied from $0 \mathrm{mg} / \mathrm{l}$ to $1.00 \mathrm{mg} / \mathrm{l}$ with mean value of $0.16 \mathrm{mg} / \mathrm{l}$ during pre-monsoon and between 0 $\mathrm{mg} / \mathrm{l}$ to $0.97 \mathrm{mg} / \mathrm{l}$ with mean value of 0.16 during post monsoon. Its shows that in the study area the nitrate concentration might be within $10 \mathrm{ppm}$ when the growth of algae if we observed. Algal growth decline DO level causing mortality of fishes and contaminate further. As per, farmer observation they found small worms and dead fishes in their drinking water its shows the DO level of water is low in that water. Water is cloudy with moderate turbidity within the range of 0-50 NTU during winter and after irrigation.

Eutrophication is a key factor causing degradation of water quality of dug well. In these area farmers using un-decomposed manure and fertilizer for substitute, so definitely $80 \%$ chances of nitrate, nutrients, $E$ coli presence in water through leaching as well as seepage. People of the surrounding villages were interviewed and water testing analysis were took placed following symptoms in water bodies was observed. 
Water moving through soil carries many soluble ions with it in the process of leaching which is a natural phenomenon occurring following rainfall or irrigation exceeds the field capacity of soil. Since nitrate is soluble in water and mobile in the soil, it readily moves with any water passing beyond the root zone. Given sufficient time and water, nitrate may eventually reach groundwater and running water through our drinking tape water.

\section{Results and Discussion}

The impact of agriculture on water quality is definitely acknowledged due to increase rate of nutrient supply in dug well not directly but through seepage or leakages during irrigation period boost the algae population in dug well. Keeping above observations in mind the following recommendations and suggestions are very important to keep the water around to the safe limit for drinking purpose.

The desirable limits of nitrates in nature are below 5ppm which generally, a very low nitrates. In fresh drinking water, nitrates should be kept below 10ppm to reduce algae growth as well as reduce prevent health hazard. Similarly, for aquariums, nitrates should be kept below 50 ppm at all times, preferably below $25 \mathrm{ppm}$.

It is regulated in drinking water primarily because excess levels can cause methemoglobinemia, or "blue baby" disease. In this area children are facing problem of low $\mathrm{Hb}$ and pregnant women also facing such problem.

It was also observed that in Leh area chemical fertilizer utilization remain varies from 4171 to 9940 quintals from1998 to 2018 and more chances of water pollution in this area due to vegetable grower.
Water quality is cloudy, opaque, and muddy taste. Its changes its color during winter and after irrigation in summer. Its range varies from 0-50NTU. As for drinking purpose it should be less then 5NTU.So proper filter unit is must this areas.

Before supply water to public, nitrates levels should be checked every fortnightly so, you know if the levels are unusually high in your as per the particular water source. If nitrates are above 10 ppm, one should consider other water sources that are free of nitrates.

As the Dug-well should be well protected if human consumption is concerned and should be covered with lid and walls to reduce lighting where there is direct sunlight for even part of the day. Sunlight can, and will, sometimes provide desired level of temperature at high altitude to promote algae growth. When using artificial light, make sure it is not stronger than necessary and is not on more than about eight hours each day.

\section{Drain water reservoir}

The single most important way to avoid algae is to perform regular water changes through drains at least 10 to $15 \%$ water should change.

Regular water testing of dug well before supply to public; and also, to check nitrates level sometime water sources have high elevated nitrates.

\section{Clean of dug well}

If algae beginning to grow on the, rocks, or other hard surfaces of the well the remove it. Scrape the glass, remove rocks, and scrub them. Vacuum the gravel when you perform water changes. Frequently chlorination is must. 
Int.J.Curr.Microbiol.App.Sci (2019) 8(9): 1447-1455

Fig.1

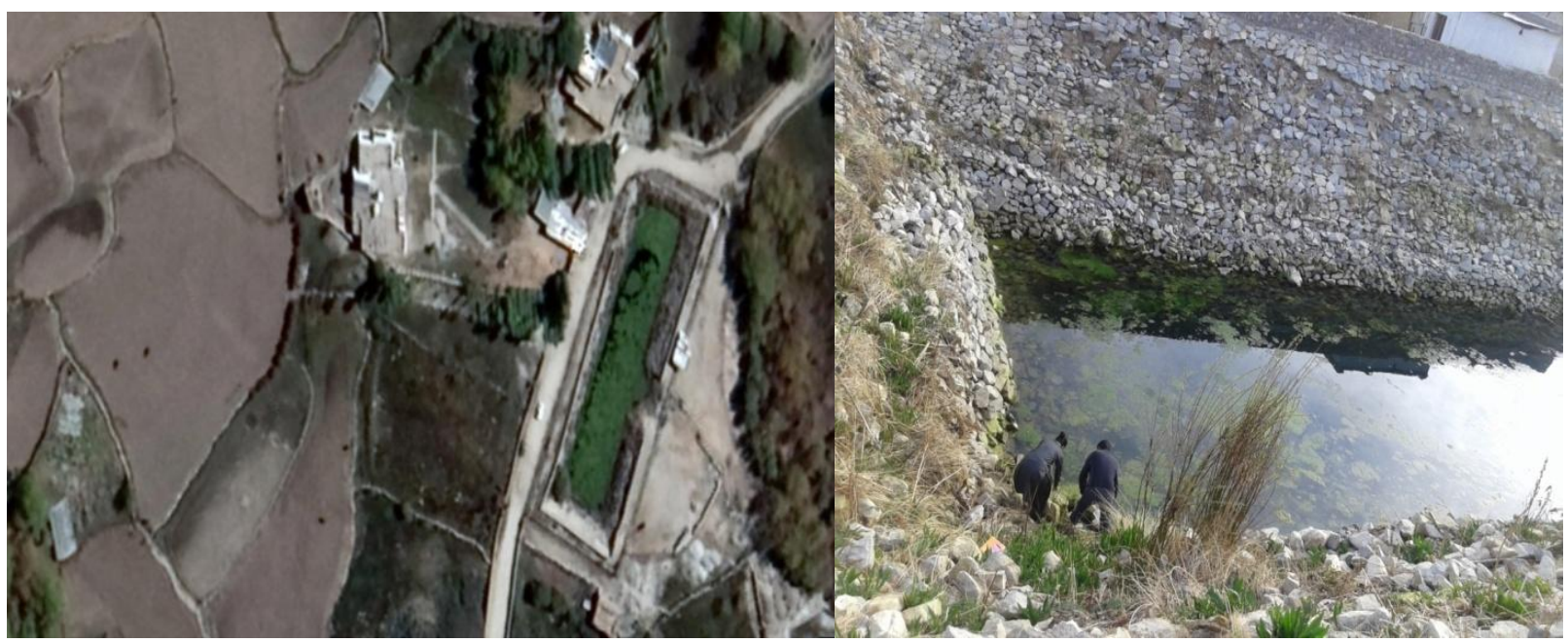

Fig.2

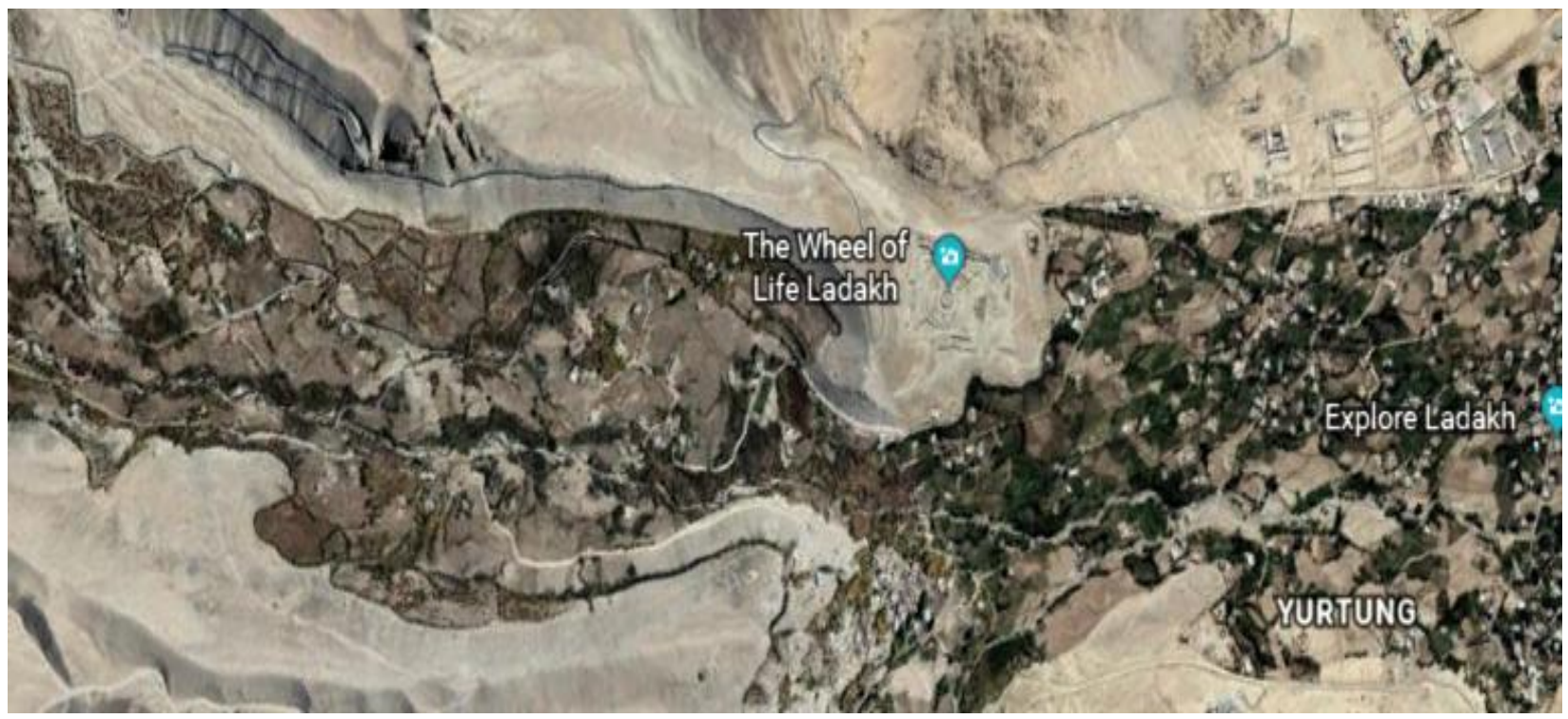


Table.1

\begin{tabular}{|c|c|c|c|c|c|}
\hline S.No. & Parameter & $\begin{array}{l}\text { Max. permissible } \\
\text { limit for drinking } \\
\text { water }\end{array}$ & $\begin{array}{l}\text { Desirable } \\
\text { limit }\end{array}$ & $\begin{array}{l}\text { Observed } \\
\text { Data }\end{array}$ & Remark \\
\hline 1 & Turbidity & $<5 \mathrm{NTU}$ & $<1 \mathrm{NTU}$ & $<50 \mathrm{NTU}$ & Moderate turbidity \\
\hline 2 & Color & & & Opaque & $\begin{array}{l}\text { Due to seepage } \\
\text { from agriculture } \\
\text { land }\end{array}$ \\
\hline 3 & Odor & & & Muddy smell & \\
\hline 4 & $\begin{array}{l}\text { Temperature } \\
\text { of water }\end{array}$ & $<25^{\circ} \mathrm{C}$ & $<10{ }^{\circ} \mathrm{C}$ & $27^{0} \mathrm{C}$ & $\begin{array}{l}\text { Exposure of direct } \\
\text { sunlight }\end{array}$ \\
\hline 5 & $\mathrm{pH}$ & & 6.6 to 8.4 . & 5.2 & Acid in nature \\
\hline 6. & TDS & $2000 \mathrm{mg} / \mathrm{l}$ & $<500 \mathrm{ppm}$ & $>250 \mathrm{ppm}$ & $\begin{array}{l}\text { Slightly high for } \\
\text { drinking }\end{array}$ \\
\hline 7. & Nitrate & $<10 \mathrm{mg} / \mathrm{l}$ & $1 \mathrm{mg} / 1$ & $<10 \mathrm{ppm}$ & $\begin{array}{l}\text { Chances } r \\
\text { leaching in dug } \\
\text { well after seeing } \\
\text { Algae growth }\end{array}$ \\
\hline
\end{tabular}

\section{Maintaining algae-eating fish}

Keeping Siamese flying fox, otocinclus, or even the common plecostomus, will help reduce some of the algae in the dug well.

Installation of high quality water filtration unit;

Community and policy makers' initiatives to conserve ponds of Ladakh

Water consumption policy is required to be framed to including all stakeholders to maintain pond for drinking purpose;

Timely Maintenance of dug-well.

Punishment or penalty should be imposed to avoid adulteration with human consumptive water body.

\section{References}

Bechmann M. 2014. Nitrogen losses from agriculture in the Baltic Sea region. Agriculture, Ecosystems and Environment. 198(15): 13-24.

Billen G., Garnier J. and Lassaletta, L. 2013. The nitrogen cascade from agricultural soils to the sea: modeling nitrogen transfers at regional watershed and global scales. Philosophical Transactions of the Royal Society 368: $1-13$.

Boyer, E.W., Goodale, C.L., Jaworski, N.A. and Howarth, R.W. 2002. Antropogenic nitrogen sources and relationships to riverine nitrogen export in the northeastern USA. Biogeochemistry 57(58): 137-169.

Cakmak, I. 2005. The role of potassium in alleviating determinable effects of abiotic stresses in plants. Journal of Plant Nutrition and Soil Science 168: 521-530.

Codex of Good Agricultural Practice. Ministry of Agriculture and Rural Development. Varsow: Ministry of the Environment; 2004.

Fageria, V.D. 2001. Nutrient interactions in 
crop plants. Journal of Plant Nutrition 2498: 1269-1290.

Fowler, D., Coyle, M., Skiba, U., Sutton, M.A., Cape, J.N. and Reis, S. 2013. The global nitrogen cycle in the twenty-first century. Philosophical Transactions of the Royal Society 368: 201-210.

Garnier, M., Recanatesi, F., Ripa, M.N. and Leone, A. 2010. Agricultural nitrate monitoring in a lake basin in central Italy: a further step ahead towards an integrated nutrient management aimed at controlling water pollution. Environmental Monitoring and Assessment 170: 273-286.

GUS (1952, 1961，1971，1981，1991，2010, 2011, 2013). Central Statistical Office of Poland; http://stat.gov.pl/

Gusewell, S. 2004. N: P ratios in terrestrial plants: variation and functional significance. New Phytologist. 164: 243266.

Gusewell, S., Koerselman, W. and Verhoeven, J.T.A. 2003. N: $\mathrm{P}$ ratios as indicators of nutrient limitation for plant populations in wetlands. Ecological Applications 13(2): 372-384.

Hatano, R., Nagumo, T. and Kuramochi, K. 2005. Impact of nitrogen cycling on stream water quality in a basin associated with forest, grassland, and animal husbandry, Hokkaido, Japan. Ecological Engineering 24: 509515.

Iital, A., Kloga, M., Pihlak, M., Pachel, K., Zahharov, A. and Loigu, E. 2014. Nitrogen content and trends in agricultural catchments in Estonia. Agriculture Ecosystems and Environment 198: 44-53.

Jiang, R., Hatano, R., Zhao, Y., Woli, K.P., Kuramochi, K., Shimizu, M. and Hayakawa, A. 2014. Factors controlling nitrogen and dissolved organic carbon exports across timescales in two watersheds with different land uses. Hydrological Processes 28: 51055121.

Kyllmar, K., Bechmann, M., Deelstra, J., Iital, A., Blicher-Mathiesen, G. and Jansons, V. 2014. Long-term monitoring of nutrient losses from agricultural catchments in the Nordic-Baltic region: a discussion of methods, uncertainties and future needs. Agriculture, Ecosystems \& Environment 198: 4-12.

Dolma, K., Rishi, M.S. and Herojeet, R. 2015. Baseline Study of Drinking Water Quality- A Case of Leh Town, Ladakh (J\&K), India. Hydrology Current Research 6(1): 100-108.

Dolma, K., Rishi, M.S. and Lata, R. 2015. An Appraisal of Centralized Waste Water Treatment Plant with Respect to Leh Town. International Journal of Science and Research 4(5): 121-129.

Kyllmar, K., Stjernman, Forsberg L, Andersson S. and Martensson, K. 2014. Small agricultural monitoring catchments in Sweden representing environmental impact. Agriculture, Ecosystems \& Environment 198: 25-35.

Lawniczak, A.E., Choinski, A. and Kurzyca, I. 2011. Dynamics of Lake Morphometry and bathymetry in various hydrological conditions. Polish Journal of Environmental Studies 20(4): 931-940.

Lawniczak, A.E., Gusewell, S. and Verhoeven, J.T.A. 2009. Effect of N: K supply ratios on the performance of three grass species from herbaceous wetlands. Basic and Applied Ecology 10(8): 715-725.

Romheld, V. and Kirkby, E.A. 2010. Research on potassium in agriculture: needs and prospects. Plant and Soil 335(1-2): 155180.

Rozemeijer, J., Klein, J., Broers, H., TolLeenders, T. and Grift, B. 2014. Water quality status and trends in agriculturedominated headwaters; a national monitoring network for assessing the 
effectiveness of national and European manure legislation in The Netherlands. Environmental Monitoring and Assessment 186(12): 8981-8995.

Szczepaniak, W., Barłog, P., Lukowiak, R. and Przygocka-Cyna, K. 2013. Effect of balanced nitrogen fertilization in fouryear rotation on plant productivity. Journal of Central European Agriculture 14(1): 64-77.
Wendland, F., Behrendt, H., Gomann, H.U., Hirt, P., Kreins, U. and Kuhn, R. 2009. Determination of nitrogen reduction levels necessary to reach groundwater quality targets in large river basins: the Weser basin case study, Germany. Nutrient Cycling in Agroecosystems 85: 63-78.

\section{How to cite this article:}

Jigmet Yangchan, Sonam Dawa, M. S. Raguwanshi, Phuntsog Tundup and Vikas Gupta 2019. Impact of Agriculture and Land Use on Ground Water Quality: A Case Study of Ladakh Cold Arid Region. Int.J.Curr.Microbiol.App.Sci. 8(09): 1447-1455.

doi: https://doi.org/10.20546/ijcmas.2019.809.166 